\title{
Морфологические особенности «Жития Св. Феодора» (1913) на удмуртском языке
}

\author{
Безенова Мария Петровна, Удмуртский институт истории, языка и литературы УдмФИЦ УрО РАН (Ижевск), \\ Институт системного программирования им. В. П. Иванникова РАН (Москва); mary_kaj@mail.ru
}

В статье рассматриваются морфологические особенности перевода «Жития Св. Феодора» (1913 г.) на елабужское наречие удмуртского языка. Актуальность исследования обусловлена тем, что письменные памятники являются одним из основных источников изучения истории языка, однако большинство памятников удмуртской письменности на данный момент еще не рассмотрено.

В работе описываются основные грамматические категории имени существительного (число, притяжательность, падеж) и глагола (залог, наклонение, время), а также неспрягаемые формы глагола (инфинитив, причастие, деепричастие). Анализ морфологических особенностей проводится на основе выявленных ранее графических и фонетических особенностей письменного источника. При этом задействован метод сопоставления языкового материала памятника с данными литературного языка и современных удмуртских диалектов. По возможности также затрагиваются вопросы происхождения морфологических маркеров с целью выявления инновационного либо архаичного характера особенностей, отраженных в исследуемом памятнике на морфологическом уровне.

В результате анализа нам удалось выявить ряд особенностей в оформлении маркеров множественного числа, деепричастий, некоторых падежных и временных форм, посредством которых язык памятника отличается от современного литературного удмуртского языка и некоторых его диалектов. При этом все они зафиксированы в современных южноудмуртских говорах, что не противоречит гипотезе, выдвинутой нами ранее на основе анализа фонетической системы памятника, согласно которой диалектной основой «Жития Св. Феодора» является один из центрально-южных говоров.

Ключевые слова: удмуртский язык, диалектология, памятники письменности, морфологические особенности

\section{MORPHOLOGICAL FEATURES OF "THE LIFE OF ST. THEODORE" (1913) WRITTEN IN THE UDMURT LANGUAGE}

Maria P. Bezenova,

Udmurt Institute of History, Language and Literature Udmurt Federal Research Center of the Ural Branch, RAS (Izhevsk);

Ivannikov Institute for System Programming, RAS (Moscow); mary kaj@mail.ru

The article examines the morphological features of the translation of "The Life of St. Theodore" (1913) into the Elabuga dialect of the Udmurt language. The significance of the study lies in the fact that although written records are one of the main sources for studying language history, most of Udmurt written records have not been examined yet.

The paper describes the main grammatical categories of the noun (number, possession, case) and the verb (voice, mood, tense), as well as those of the non-conjugated verb forms (infinitive, participle, adverbial participle). The analysis of morphological characteristics is based on the previously identified graphic and phonetic features of the written source and employs a comparative method: the linguistic data were compared with the data from the literary language and modern Udmurt dialects. Furthermore, whenever possible, the issues of the origin of morphological markers are raised in order to identify the innovative or archaic nature of the characteristics which are reflected in the written record at the morphological level.

As a result, a number of features in the formalization of plural indicators, adverbial participles, some case and tense forms are revealed, which make the language of the written record different from the modern literary Udmurt language and some of its dialects. At the same time, all of these features are preserved in modern South Udmurt dialects, which does not contradict the hypothesis put forward earlier and based on the analysis of the phonetic system of the source text, according to which the dialect basis of "The Life of St. Theodore" is one of the Central-Southern dialects.

Keywords: the Udmurt language, dialectology, written records, morphological features

Работа выполнена при поддержке проекта РНФ № 20-18-00403 «Цифровое описание уральских языков на основе больших данных». 


\section{1. Введение}

Статья посвящена описанию морфологических особенностей перевода «Жития Св. Феодора» (1913 г.) на елабужское наречие удмуртского языка. Графические и фонетические особенности памятника были подробно проанализированы в работе [Безенова 2021]. В данной статье рассматриваются основные грамматические категории имени существительного (число, притяжательность, падеж) и глагола (залог, наклонение, время), характерные для удмуртского литературного языка и его диалектов, а также неспрягаемые формы глагола.

Описание морфологических особенностей проводится методом сопоставления языкового материала памятника с данными литературного языка и современных удмуртских диалектов. По возможности также затрагиваются вопросы происхождения морфологических маркеров с целью выявления инновационного либо архаичного характера особенностей, отраженных в переводе «Жития Св. Феодора» на морфологическом уровне.

\section{2. Именная морфология}

\section{1. Число}

Категория числа в [Житие], как и в современном удмуртском языке, выражается противопоставлением форм единственного и множественного числа. Для форм единственного числа характерно отсутствие формальных показателей (ср. иньты 'место' - литер. инты, ву 'вода' — литер. ву, дыр 'время' — литер. дыр). Формы множественного числа имен существительных в памятнике, как правило, образуются с помощью суффикса -ёс , который присоединяется как к основам на гласные, так и к основам на согласные:

гижлоёсаз 'на его язвы' PL-ILL-POSS.3SG - литер. гижлоосаз; иньтыёс 'места' PL — литер. интыюс, иньтыёсьзз 'места' PL-ACC — литер. интылосты/ интылосыз, иньтыёслы 'местам' PL-DAT — литер. интылосльl, иньтыёсэ 'в места' PL-ILL - литер. интыьосы, иньтылёсаз 'в его местах' PL-INE-POSS.3SG - литер. интыьосаз; книгаёсыз 'книги' PL-ACC - литер. книгаосты/книгаосыз (ср. книгаос 'книги' PL — литер. книгаос); кышноёс 'женщины' PL — литер. кышноос (ср. кышноосль 'женщинам' PL-DAT — литер. кышноослы); періёсыз періосыз 'злых духов' PL-ACC — литер. периосты/периосыз;

аръёс 'годы' PL - литер. аръёс; дышечкисьёсыз 'его ученики' PL-POSS.3SG - литер. дышетскисьёсыз, дылеткисьёсызль 'его ученикам' PL-POSS.3SG-DAT — литер. дышетскисьёсызль; тӥрлыкъёс 'изделия’ PL — литер. тӥрлькъёс; ужъёс ‘дела' PL — литер. ужъёс, ужъёслэсь 'от дел’ PL-ABL — литер. ужъвёслэсь; улӥсьёс 'живущие' PL 一 литер. улӥсьёс и т. д.

Как видим, в отличие от памятника, в удмуртском литературном языке после основ с финальной гласной употребляется маркер -оc. В [Житие] данный показатель выступает лишь в форме множественного числа русского заимствования чудооссэ 'его чудеса' PL-POSS.3SG-ACC - литер. чудооссэ, а также в двух случаях функционирует параллельно с показателем -ёс (примеры приведены выше).

Образование форм множественного числа с помощью суффикса -йос от основ с конечной гласной зафиксировано и в отдельных удмуртских говорах. Более системно это явление представлено в буйскотаныпском и татышлинском говорах периферийно-южного диалекта [Кельмаков 2006: 116] и в косинском говоре нижнечепецкого диалекта [Карпова 2018: 168]. Спорадически подобные формы встречаются и в некоторых других говорах северного наречия [Карпова 2018: 169], а также в центрально-южном диалекте [Атаманов 1981: 52; Загуляева 1982: 6].

По поводу происхождения морфологического показателя множественного числа в пермских языках существуют различные гипотезы [Лыткин 1931: 108; Uotila 1933: 182-183; Kövesi 1965: 152; Кондратьева 2011б: 36 и др.], согласно которым в составе данного маркера изначально был согласный $\breve{u}$, который в словах на конечную гласную в результате ослабления в интервокальном положении был утрачен. Таким образом, вероятно, из двух показателей множественного числа, которые представлены в современном удмуртском языке и в большинстве его диалектов, -оc имеет более инновационный характер, а -ёс, который характерен и для текста памятника, по своему происхождению является архаичным.

\section{2. Притяжательность}

Морфологически категория посессивности в удмуртском языке выражается различными личнопритяжательными суффиксами. В таблицах 1 и 2 представлены притяжательные формы, которые нам удалось выявить в переводе «Жития Св. Феодора» на удмуртский язык, и их литературные соответствия. 
Таблииа 1. Выражение категории посессивности в памятнике (формы индивидуального обладателя)

\begin{tabular}{|c|c|c|}
\hline Лицо & Одно обладаемое & Много обладаемых \\
\hline 1 & $\begin{array}{l}\text { анае ‘моя мать' POSS.1SG - литер. анае } \\
\text { піе ‘мой сын' POSS.1SG - литер. пие } \\
\text { сьӧльлке ‘мой грех' POSS.1SG - литер. сьӧльлке }\end{array}$ & $\begin{array}{l}\text { калькъвёсме ‘моих людей’ PL-POSS.1SG-ACC- } \\
\text { литер. калькъёсме }\end{array}$ \\
\hline 2 & $\begin{array}{l}\text { анаед ‘твоя мать’ POSS.2SG - литер. анаед } \\
\text { пидэ ‘твоего сына' POSS.2SG-ACC - литер. пидэ } \\
\text { улэмед ‘твоя жизнь' POSS.2SG - литер. улэмед }\end{array}$ & не зафиксировано \\
\hline 3 & $\begin{array}{l}\text { анаез 'его мать' POSS.3SG - литер. анаез } \\
\text { піез 'его сын' POSS.3SG - литер. пиез } \\
\text { сузэрез 'его сестра' POSS.3SG - литер. сузэрез } \\
\text { нимыныз 'его именем' INS-POSS.3SG - литер. нимыныз } \\
\text { тӱсыз 'его образ' POSS.3SG - литер. тусыз }\end{array}$ & $\begin{array}{l}\text { дорисьёсыз ‘его домашние’ PL-POSS.3SG- } \\
\text { литер. дорысьёсыз } \\
\text { дымечкисьёсыз ‘его ученики’ PL-POSS.3SG- } \\
\text { литер. дышетскисьёсыз } \\
\text { монахъёсыз ‘его монахи’ PL-POSS.3SG- } \\
\text { литер. монахъёсыз }\end{array}$ \\
\hline
\end{tabular}

Таблица 2. Выражение категории посессивности в памятнике (формы коллективного обладателя)

\begin{tabular}{|c|c|c|}
\hline Лицо & Одно обладаемое & Много обладаемых \\
\hline 1 & $\begin{array}{l}\text { вӧсяськеммы ‘наше моление’ POSS.1PL- } \\
\text { литер. вӧсяськеммы } \\
\text { яраномес ‘нашу годность' POSS.1PL-ACC - } \\
\text { литер. яраномес }\end{array}$ & не зафиксировано \\
\hline 2 & пьлдәэс 'вашу ногу’ POSS.2PL-ACC - литер. пьлддэс & не зафиксировано \\
\hline 3 & 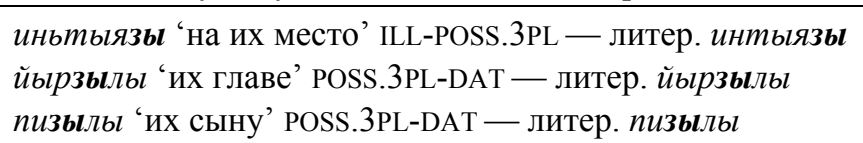 & не зафиксировано \\
\hline
\end{tabular}

Как видим, притяжательные формы памятника идентичны литературным. В [Житие] мы обнаружили лишь один пример, не соответствующий современной норме удмуртского языка: мурты 'мой человек' POSS.1SG - литер. муртэ. Объясняется данное отклонение наличием в удмуртском языке двух вариантов огласовок притяжательных маркеров во всех трех лицах в случае единственного числа обладателя и обладаемого (ср. -э (-e), -bl 'мой, моя, мое'; -эд (-ед), -ыл 'твой, твоя, твое'; -эз (-ез), -ыз 'его, ее'). По мнению одних лингвистов, $b$-овые огласовки связаны с семантическими признаками имен существительных [ГСУЯ 1962: 82-83], по мнению других, корни данного явления уходят в историческую фонетику [Fokos 1963: 217], по мнению третьих, подобная система притяжательных маркеров сложилась в результате прохождения трех этапов: «фонетического», «семантического» и «морфологического» [Кельмаков 1993: 26]. При этом третий этап, при котором «под действием аналогии происходит постепенное поглощение небольшой $b l$-группы имен существительных э-группой через промежуточную ступень варьирования у них форм на -bl и -э» [Кельмаков 1993: 27], мы активно наблюдаем сейчас как в литературном языке (виры $\sim$ вире 'моя кровь', тылылд тылэә 'твой огонь', кылыз кылэз 'его слово'), так и в удмуртских диалектах (юж. вил'ы // сред. выл'эз 'новое', кукм. чужмортъд // сред. ӥужмуртэд 'твой дядя (по матери)' [Кельмаков 2006: 117]).

\section{3. Падеж}

Система склонения литературного удмуртского языка включает 15 падежей, которые формально подразделяются на две группы: а) субъектно-объектные падежи: именительный (номинатив), винительный (аккузатив), родительный (генитив), разделительный (аблатив), дательный (датив), творительный (инструменталь), лишительный (абессив), соответственный (адвербиаль); б) пространственные падежи: местный (инессив), входный (иллатив), исходный (элатив), отдалительный (эгрессив), переходный (пролатив), предельный (терминатив), направительный (аппроксиматив). В диалектах удмуртского языка количество падежей варьируется от 12 до 21 [Кондратьева 2011a: 16]. В частности, во многих периферийноюжных и некоторых центрально-южных говорах количество падежей сократилось до $12-13$ вследствие 
замещения адвербиальных, аппроксимативных и в отдельных случаях терминативных форм послеложными конструкциями, например: кркм. ад'амийос с'аин 'в соответствии с людьми, по-людски' - литер. адямиосъя, адямиос сямен; кркм. гурт пала 'в сторону деревни, по направлению к деревне' - литер. гуртлань, гурт пала; бтБК. вал дыроз' ‘до лошади' - литер. валозь, вал дорозь и др. [Кельмаков 2006: 117-118]. В бесермянском наречии удмуртского языка, а также в среднечепецком и нижнечепецком диалектах северного наречия, напротив, наблюдается увеличение количества падежных форм за счет возникновения серии вторичных локальных падежей «с приметой $-H^{\prime}-\left(<\partial u \mu^{\prime}-\right.$ 'у, около, при, возле'), препозитивно присоединяемой ко всем первичным пространственным падежным формантам, за исключением аппроксиматива (-лан)», например: бускэл'-н'blн 'у соседа' - литер. бускель дорын, бускэл'-н'blс' 'от соседа' - литер. бускель дорысь, бускэл'-н'э 'к соседу' - литер. бускель доры и т. д. [Кельмаков 2006: 118-119].

В таблице 3 мы представили все падежные маркеры, функционирующие в анализируемом памятнике. Как видим, в [Житие] нам удалось выявить лишь 12 членов парадигматического ряда. Абессивные, адвербиальные и аппроксимативные формы в памятнике мы не зафиксировали. Отсутствие форм лишительного падежа в «Житии Св. Феодора» на удмуртском языке, вероятно, связано с его относительно небольшим объемом (17 страниц) и, в свою очередь, с отсутствием семантически подходящих контекстов. С одной стороны, этим же можно объяснить и то, что в тексте нам не удалось выявить соответственный падеж; хотя, с другой стороны, как мы указали выше, для отдельных южных диалектов в целом характерна замена подобных форм послеложными конструкциями, которые встречаются в тексте памятника, ср.: верамез сямен 'согласно сказанному им' - литер. верамезъя, верамез сямен; косэмез сяин 'по его велению' - литер. косэмезъя, косэмез сямен и др. Однако что касается направительного падежа, в [Житие] отсутствуют не только словоформы, маркированные суффиксом -лань, но и конструкции с послелогом пала 'к, в сторону, на', которые могли бы их заменить. Вероятно, это связано с тем, что аппроксиматив является «одним из самых редкоупотребительных падежей в современном удмуртском языке» [Кондратьева 2011а: 204].

Из таблицы видно, что в оформлении отдельных падежных показателей памятника по сравнению с литературной нормой прослеживаются некоторые особенности.

\subsection{1. Маркером винительного падежа множественного числа в [Житие] является суффикс -ыз:}

висисьёсыз ‘больных’ PL-ACC - литер. висисьёсты/ висисьёсыз;

иньтыёсыз 'места' PL-ACC - литер. интыосты /интыосыз;

кылъёсыз 'слова' PL-ACC - литер. кылъёстыл/кылъёсыз и др.

Как видим, в литературном языке на данный момент в этой роли функционируют два синонимичных показателя -mbl и -blз. Однако что касается удмуртских диалектов, в данном случае их употребление зависит от конкретной диалектной зоны: маркер -mbl/-mъ характерен для говоров северной диалектной зоны, которая включает в себя северное и бесермянское наречия, а также часть срединных говоров, а суффикс -blз/-ъз представлен в говорах южной диалектной зоны, охватывающей южное наречие и южную часть срединных говоров (см. подробнее [Тепляшина 1975: 180-181]). Относительно происхождения этих показателей существуют различные гипотезы (подробнее см. [Кондратьева 2011в: 117-118]), однако, по мнению ученых, оба маркера, скорее всего, восходят к прапермскому периоду [Кельмаков 2006: 120; Кондратьева 2011в: 118].

2.3.2. Для образования форм разделительного падежа в памятнике параллельно с суффиксом -лэсь, идентичным литературному, употребляется суффикс -лӥсь, ср.:

1) -лэсь:

Георгійлэсь 'от Георгия' ABL - литер. Георгийлэсь;

Іисусъ Христослэсь 'от Иисуса Христа' ABL — литер. Иисус Христослэсь;

кортлэсь 'из железа' ABL - литер. кортлэсь;

кышнолэсь 'от женщины' ABL - литер. кышнолэсь;

святойлэсь 'от святого' ABL - литер. святойлэсь;

эксэйлэсь 'от царя' ABL - литер. эксэйлэсь;

ветлонэзлэсь 'от его хождения' POSS.3SG-ABL — литер. ветлонэзлэсь;

висёнэзлэсь 'от его болезни' POSS.3SG-ABL — литер. висёнэзлэсь;

кулэмезлэсь 'от его смерти' POSS.3SG-ABL - литер. кулэмезлэсь;

піезлэсь 'от его сына' POSS.3SG-ABL — литер. пиезлэсь;

ужъёслэсь 'от дел’ PL-ABL — литер. ужъёслэсь. 
Таблица 3. Падежные маркеры имен существительных

\begin{tabular}{|c|c|c|c|c|}
\hline \multirow{2}{*}{ Падеж } & \multicolumn{2}{|c|}{ Единственное число } & \multicolumn{2}{|c|}{ Множественное число } \\
\hline & [Житие] & литер. & [Житие] & литер. \\
\hline номинатив & $\boldsymbol{o}(52)^{1}$ & o & $\boldsymbol{o}(17)$ & o \\
\hline \multirow{4}{*}{ аккузатив } & $-9 /-e(44)$ & $-9 /-e$ & $-\boldsymbol{b l 3}(9)$ & $-m b l /-b l 3$ \\
\hline & $\boldsymbol{o}(30)$ & $\boldsymbol{O}$ & & \\
\hline & $-93 /-е 3(17)$ & $-93 /-e 3$ & & \\
\hline & $-\ni c /-e c(5)$ & $-э c /-e c$ & & \\
\hline генитив & -лэн (18) & $-л э н$ & -лэн (2) & -лэн \\
\hline \multirow{3}{*}{ аблатив } & -лэсь (10) & $-л э с \boldsymbol{c}$ & $-л э с \boldsymbol{c}(1)$ & $-л э с \boldsymbol{c}$ \\
\hline & $-л \ddot{и с c b ~(4) ~}$ & $-л э c b$ & & \\
\hline & -лӥсь $\sim-л э с ь$ (3) & $-л э с \boldsymbol{c}$ & & \\
\hline датив & $-\boldsymbol{л b \boldsymbol { l }}(32)$ & $-\pi b \boldsymbol{l}$ & $-\pi \boldsymbol{b}(5)$ & $-\pi \boldsymbol{b l}$ \\
\hline \multirow{3}{*}{ инструменталь } & $-э \boldsymbol{-} /$-ен $(15)$ & $-э \boldsymbol{H} /-е \mathrm{H}$ & $-\boldsymbol{b l h}(1)$ & $-b l \boldsymbol{H}$ \\
\hline & -энbl-/-ень- (7) & -энbl-/-енbl- & & \\
\hline & -blнbl- (3) & -blHbl- & & \\
\hline абессив & не зафиксировано & - -тэк & не зафиксировано & $-m э \kappa$ \\
\hline адвербиаль & не зафиксировано & $-\boldsymbol{A}$ & не зафиксировано & $-\boldsymbol{A}$ \\
\hline \multirow{4}{*}{ инессив } & $-\boldsymbol{b l h}(12)$ & $-b l h$ & $-\boldsymbol{b l h}(2)$ & $-b l H$ \\
\hline & $-a-/-я-(6)$ & $-a-/-g-$ & & \\
\hline & $-\boldsymbol{H}(2)$ & $-\boldsymbol{H}$ & & \\
\hline & $\boldsymbol{o}(1)$ & $\boldsymbol{o}$ & & \\
\hline \multirow{2}{*}{ иллатив } & $-9 /-e(16)$ & $-3 /-e$ & $-\ni(1)$ & $-b \boldsymbol{l}$ \\
\hline & $-a-/-\boldsymbol{r}-(11)$ & $-a-/-\boldsymbol{x -}$ & & \\
\hline \multirow{3}{*}{ элатив } & $-и c b /-\ddot{u} c b(10)$ & $-b l c b$ & $-\boldsymbol{b l c b}(1)$ & $-b l c b$ \\
\hline & $-\boldsymbol{b l c b}(1)$ & $-\boldsymbol{b l c b}$ & & \\
\hline & -ucbmbl-/-ücbmbl- (5) & -blcbmbl- & & \\
\hline эгрессив & $\begin{array}{c}\text {-исен/-ӥсен (3) } \\
\text {-исень-/-ӥсень- (1) }\end{array}$ & $\begin{array}{c}\text {-ысен } \\
\text {-ысень- }\end{array}$ & не зафиксировано & -ысен \\
\hline пролатив & $-m \ddot{u}-(1)$ & $-m \ddot{u}-$ & не зафиксировано & $-m \ddot{u}$ \\
\hline терминатив & $-\boldsymbol{o c b}(1)$ & $-03 b$ & не зафиксировано & $-03 b$ \\
\hline аппроксиматив & не зафиксировано & -лань & не зафиксировано & -лань \\
\hline
\end{tabular}

2) -лӥсь:

Стефанлиїсь 'от Стефана' ABL — литер. Стефанлэсь;

чамалӥсь 'от чаши' ABL - литер. чамалэсь;

эксэйлыглиїсь 'от царства' ABL — литер. эксэйльклэсь;

корказылӥсь 'от их дома' POSS.3PL-ABL — литер. корказылэсь.

3) -лӥсь $\sim-л э с ь$

Инмарлӥсь Инмарлэсь 'от Бога' ABL - литер. Инмарлэсь;

Өеодорлӥсь Өеодорлэсь 'от Феодора' ABL — литер. Феодорлэсь;

анаезлӥсь анаезлэсь 'от его матери' POSS.3SG-ABL — литер. анаезлэсь.

Отметим, что вариант с гласным $u$ встречается и в отдельных удмуртских говорах, а именно в кукморском, шошминском, канлинском, а также в бесермянском наречии удмуртского языка, ср. кукм., шошм., канл. анай-лис', бес. анай-лис' анай-лъс' 'у (от) матери' [Кельмаков 2006: 120]. В бавлинском говоре периферийно-южного наречия зафиксировано параллельное употребление алломорфов -лис' и -лэс', cp. atajlis' atailes' ‘у (от) отца' [Тараканов 1960: 133]. Из двух вариантов менее распространенный -лис', вероятно, все-таки имеет более архаичное происхождение, поскольку в данном случае мы имеем прямые параллели в коми языках, ср.: к.-я. -лись, к.-п. -лысь/-лісь, к.-з. -лысь [Усачева 2011: 209]. На ос-

1 Здесь и далее в скобках указано количество словоформ с тем или иным падежным показателем, которые нам удалось выявить в [Житие]. 
нове этих соответствий, как полагает В. К. Кельмаков, для прапермского периода можно реконструировать форму *-liś(t-) [Кельмаков 2006: 121] (ср. *-liśt [Серебренников 1963: 83]).

2.3.3. Форма множественного числа входного падежа в памятнике образуется с помощью маркера -э в соответствии с литер. -bl. Но, к сожалению, в [Житие] в данном случае представлен лишь один пример: иньтыёсэ 'в места' PL-ILL - литер. интыосы. В диалектах современного удмуртского языка, как и в рассмотренных нами ранее памятниках на глазовском и казанском диалектах, подобные формы также не зафиксированы. В связи с этим, на наш взгляд, делать какие-либо выводы о происхождении этой формы не представляется возможным.

2.3.4. Маркеры исходного и отдалительного падежей в [Житие] выступают в $u$-овой огласовке, ср.:

Анастасіополӥсь 'из Анастасиополя' ELA — литер. Анастасиопольысь;

бусыись 'с поля' ЕLA — литер. бусыbысь;

городӥсь 'из города' ELA — литер. городысь;

гуртӥсь 'из деревни' ЕLA - литер. гуртысь;

дорись 'из дома' ELA - литер. дорысь;

жугисьнонӥсь 'с битвы' ELA - литер. жугиськонысь;

иньмись $\sim$ инмись 'с неба' ELA - литер. инмысь;

музъемись 'из земли' ЕLA - литер. музъемысь;

Палестинаись 'из Палестины' ELA - литер. Палестинаысь;

черкись 'из церкви' ELA - литер. черкысь;

гуйсьтыз 'из его пещеры' ELA-POSS.3SG - литер. гуысьтыз;

кіӥсьтыз 'из его руки' ELA-POSS.3SG - литер. киысьтыз;

юамисьтыз 'из-за его расспроса' ELA-POSS.3SG - литер. юамысьтыз;

дорисьтызы 'из их дома' ELA-POSS.3PL - литер. дорысьтызы;

косэмисьтызы 'из-за их просьбы' ELA-POSS.3PL — литер. косэмысьтызы.

иньмисен 'с неба' EGR - литер. инмысен;

нуналӥсен 'с дня' EGR - литер. нунальсен;

пиналӥсенӥк 'с детства (досл. с ребенка) же' EGR — литер. пиналысен ик;

нуналисеныз нуналӥсеныз 'с его дня' EGR-POSS.3SG - литер. нуналысеныз.

Исключение составляют лишь две формы:

Іерусалимысь 'из Иерусалима' ELA — литер. Иерусалимысь;

гурезьёсысь 'с гор' PL-ELA - литер. гурезьёсысь.

Следует отметить, что $u$-овые варианты маркеров в памятнике присоединяются также к основам серийных послелогов, а кроме того, содержатся в структуре ряда наречий, обозначающих место. При этом аналогичные формы в конце XIX в. были зафиксированы в елабужском диалекте и финским ученым Ю. Вихманном, ср.:

бордӥсь 'от' - литер. бордысь; ср. bordị̂s, bordị̂ś (G), bordiś (M), bordiś (J, MU, U) 'от’ [Wichmann 1987: 26];

дорись 'от' — литер. дорысь; сp. dorị̂s (G), doriś (J, MU) 'от' [Wichmann 1987: 37];

дорисен 'от' - литер. дорысен; ср. doriśen (J, MU) 'от' [Wichmann 1987: 37];

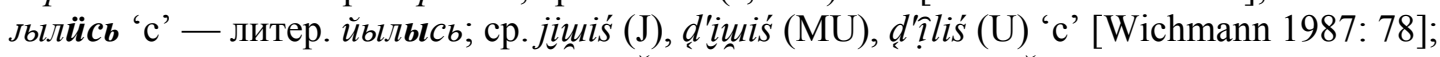

пуйкись 'из' - литер. пушкысь; ср. puș̌kiś (J, U), puškiś (J), putș̌kiś (MU) ‘из' [Wichmann 1987: 214];

улӥсь 'c' - литер. улыссь; ср. ulịs (G, U), ulר̣̂s (G), umiś, umiś (MU) 'снизу' [Wichmann 1987: 295].

кытӥсь 'откуда' - литер. кытысысь; ср. kịtịss (G, B), kitiss (M), kitiś (J, MU), ki -tiś (J) 'откуда?'

[Wichmann 1987: 127];

отӥсь 'оттуда' - литер. отысb; cp. oṭ̂ś (G), otiśs (S, M, MU), otiś (MU), otiś (MU, U) 'оттуда'

[Wichmann 1987: 183];

отӥсен 'оттуда' — литер. отысен; ср. oṭ̣śen (G, B) 'оттуда' [Wichmann 1987: 183];

татӥсь 'отсюда' - литер. татысь; cp. tàt?̣ś (G), tàtisś (M, MU), tàtiś (MU, U) 'отсюда' [Wichmann 1987: 255].

Элативные и эгрессивные показатели с $u$-овой инициалью представлены и в современных говорах удмуртского языка. Они характерны для говоров южной диалектной зоны, в том числе встречаются в центрально-южном диалекте [Архипов 1978: 16-17; Загуляева 1982: 6]. В северной диалектной зоне, 
напротив, представлены bl-овые варианты этих маркеров, идентичные литературным [Кельмаков 2006: 121]. При этом общепринято мнение, согласно которому «южноудмуртские формы на -u- имеют вторичное происхождение из более ранних форм на -bl- под влиянием последующего палатального согласного $c^{\prime} \gg$ [Кельмаков 2006: 122]. Таким образом, ясно, что $u$-овые варианты элативных и эгрессивных маркеров в памятнике имеют инновационный характер.

2.3.5. Показателем предельного падежа в памятнике выступает суффикс -ось, правда, как и в случае с входным падежом множественного числа, в тексте присутствует лишь одна форма (苾ытось 'до вечера' TER - литер. ӝ̈ытозь), хотя в данном случае она встречается в двух предложениях. Этот же маркер присоединяется к основе серийных послелогов дыр-, который в сочетании с существительными в [Житие] выражает терминатив с темпоральным значением, ср.: Пасха дырось 'до Пасхи' - литер. Пасха дырозь, Пасхаозь; нуналэз дырось 'до его дня' - литер. нуналэз дырозь, нуналозяз. Показатель -ос' $\left(-о c^{\prime} a\right)$ зафиксирован и в отдельных говорах современного удмуртского языка [Кондратьева 2011б: 170].

По поводу происхождения суффикса предельного падежа существуют различные точки зрения (подробнее см. [Кондратьева 2011в: 41-46]). Однако, если учесть соответствующие терминативные маркеры в коми языках (ср. к.-3., к.-п. -ӧдз [Баталова 1993a: 221, 1993б: 234]), уместно предположить, что вариант -озb, характерный для современного удмуртского языка, по своему происхождению является более архаичным, а алломорф, представленный в памятнике, по всей видимости, инновационным.

\section{3. Глагольная морфология}

\section{1. Залоги глагола}

В современном удмуртском языке выделяют две группы залогов: а) понудительный и непонудительный, б) возвратный и невозвратный.

3.1.1. Формы понудительного залога в [Житие], как и в современном удмуртском языке, образуются присоединением к основе глагола маркера $-\boldsymbol{m}(\boldsymbol{b l})-:$ лэсытылтэм 'он, оказывается, заставил сделать' CAUS-2PST.3SG — литер. лэсьтылээм(ез), пырытэм 'он, оказывается, заставил войти' CAUS-2PST.3SG литер. nырытэм(ез). Для форм непонудительного залога характерно отсутствие формальных показателей, ср.: лэсьтэм 'он, оказывается, сделал' 2PST.3SG - литер. лэсьтэм(ез), пырем 'он, оказывается, вошел' 2PST.3SG - литер. пьрем(ез) и др.

3.1.2. Возвратный залог, противопоставляясь невозвратному с нулевым показателем, в современном

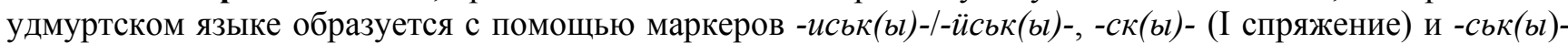
$(\mathrm{II} \text { спряжение })^{2}$. В памятнике основными показателями возвратного залога являются суффиксы:

1) -иськ(bl)-/-ӥськ(bl)-:

вӧлдӥськыса 'распространившись' REFL-CONV — литер. вӧлдӥськыса;

пилиськыса 'разбившись' REFL-CONV — литер. пилиськыса;

куриськом 'мы помолимся' REFL-FUT-1PL — литер. куриськом(bl) и др.

2) -ськ(bl)-:

вӧсяськем 'он, оказывается, молился' REFL-2PST.3SG - литер. вӧсяськем(ез);

люкаськильлям 'они, оказывается, собрались' REFL-2PST.3PL - литер. люкаськиллям(зы);

ӥогаськем 'он, оказывается, заперся' REFL-2PST.3SG - литер. ӥогаськем(ез) и др.

Однако при образовании рефлексивных форм от глаголов первого спряжения в [Житие] возможны отклонения, ср.:

аткыса ачкыса 'показавшись' REFL-CONV — литер. адӟиськыса/адскыса, аткем 'он, оказывается, показался' REFL-2PST.3SG - литер. адӟиськем(ез)/адскем(ез) (< адӟыны 'увидеть, видеть; повидать');

дымиеткыны 'обучаться' REFL-INF — литер. дыметӥськыныл/дыметскыны, дышеткон дышечкон 'предназначенный для обучения' REFL-PTCP — литер. дышетӥськон/дышетскон (< дыметыны 'учить, обучить, обучать');

${ }^{2}$ Глаголы I и II спряжения отличаются друг от друга финальной гласной основы, стоящей перед инфинитивным показателем - $b b l$ : глагольные основы с конечной -bl- относятся к I спряжению (например: мblныны 'идти, пойти',

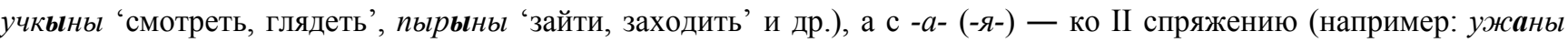
'поработать, работать', дасяны 'приготовить, готовить', бичаны 'собрать, собирать' и др.) [УКК 2011: 148]. 
куткем кучкем 'он, оказывается, начал' REFL-2PST.3SG - литер. кутӥськем(ез)/кутскем(ез), куткыса 'начав' REFL-CONV — литер. кутӥськыса/кутскыса, куткильлям 'они, оказывается, начали' REFL-2PST.3SG - литер. кутӥськиллям(зы)/кутскиллям(зы) (< кутыныь 'поймать; схватить');

пылачкон 'предназначенный для крещения' REFL-PTCP — литер. пылатӥськон, пылачкыса 'крестившись' REFL-CONV - литер. пылатӥськыса (< пылатыны 'крестить, окрестить').

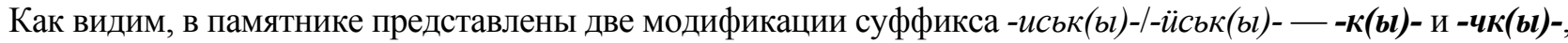
которые, как правило, возникают в результате сочетания залогового суффикса глаголов I спряжения с глагольными основами на -mbl- [Кельмаков 2006: 140]. Аналогичные варианты зафиксированы и в современных говорах удмуртского языка. При этом, по данным диалектологов, -к(bl)- встречается в большинстве срединных говоров (в Шарканском, Увинском, Селтинском, Завьяловском районах) [Кельмаков 2006: 141], а -чк(bl)- представлен в отдельных говорах центрально-южного наречия, например в кырыкмасских [Кельмаков 2006: 141] и граховских [Атаманов 1981: 69], а также в верхнечепецких говорах северного наречия [Алашеева 1982: 92]. Функционирование в памятнике обоих вариантов -к(bl)- и -чк(bl)-, возможно, свидетельствует о том, что в основе текста лежит диалект, территориально расположенный на границе южноудмуртских и срединных говоров удмуртского языка.

\section{2. Категория наклонения и временные формы}

В современном литературном удмуртском языке и большинстве его диалектов выделяют три наклонения глаголов: изъявительное, повелительное и сослагательное. Все они присутствуют и в тексте «Жития Св. Феодора».

3.2.1. Основным отличительным признаком глаголов изъявительного наклонения является их способность изменяться по временам. В удмуртском языке различают восемь временных форм: а) простые: настоящее, будущее, первое прошедшее (очевидное), второе прошедшее (неочевидное); б) сложные: I плюсквамперфект, II плюсквамперфект, прошедшее длительное и прошедшее многократное [УКК 2011: 170].

В образовании форм настоящего, будущего и первого прошедшего времени в соответствии с литературными формами особых отклонений не выявлено, ср.:

яратӥсько 'люблю' PRS.1SG - литер. яратӥсько, бӧрдӥськод 'плачешь' PRS-2SG - литер. бӧрдӥськод, туртэ 'намеревается' PRS.3SG — литер. турттэ, буре ваё 'поминают' PRS.3PL — литер. буре ваё, уг сюлмаськы 'не беспокоится' NEG.PRS.3SG - литер. уг сюлмаськы и др.;

куло 'умру' FUT.1SG - литер. куло, луод ‘станешь' FUT-2SG - литер. луод, улоз ‘будет жить' FUT-3SG литер. улоз, бертом 'возвратимся домой' FUT-1PL - литер. бертом(bl), даннялозы 'прославят' FUT-3-PL — литер. даннялозы, уг кушты 'не брошу' NEG.FUT.1SG - литер. уг кушты и др.

басьтӥ 'я взял' 1PST.1SG — литер. басьтӥ, улӥд 'ты жил' 1PST-2SG — литер. улӥд, кошкиз 'он ушел' 1PST-3SG - литер. кошкиз, дугдытӥды 'вы остановили' 1PST-2-PL — литер. дугдытӥды, ӧй тоды 'я не узнал' NEG.1PST.1SG — литер. ӧй тоды, ӧд берты 'ты не вернулся домой' NEG.1PST.2SG литер. ӧй modbl, ӧз nombl 'он не вышел' NEG.1PST.3SG — литер. ӧз nombl, ӧз лэзе 'они не отпустили' NEG.1PST.3-PL — литер. ӧз лэзе и др.

Второе прошедшее время в памятнике представлено лишь формами третьего лица единственного и множественного числа: карем 'он, оказывается, сделал' 2PST.3SG — литер. карем(ез), тодмам 'он, оказывается, узнал' 2PST.3SG - литер. тодмам; кошкильлям 'они, оказывается, ушли' 2PST.3PL — литер. кошкиллям(зы), жаляльлям 'они, оказывается, пожалели' 2PST.3PL — литер. жаляллям(зы) и др.

В образовании этих форм нам удалось выявить ряд особенностей.

1) Утвердительные и отрицательные формы 3-го лица единственного числа, образованные от глаголов I спряжения, выступают в [Житие] без личного показателя (-ез), употребление которого в литературном языке факультативно, например:

курем 'он, оказывается, попросил' 2PST.3SG - литер. курем(ез);

пуктэм 'он, оказывается, построил' 2PST.3SG - литер. пуктэм(ез);

улэм 'он, оказывается, жил' 2PST.3SG - литер. улэм(ез);

тодымтэ ‘он, оказывается, не знал’ NEG.2PST.3SG — литер. подылмтэ(ез) / ӧвӧл тодэм(ез);

косымтэ 'он, оказывается, не велел' NEG.2PST.3SG - литер. косылмтэ(ез) / ӧвӧл косэм(ез);

зорымтэ 'дождь, оказывается, не шел’ NEG.2PST.3SG - литер. зорымтэ(ез) / ӧвӧл зорем(ез) и др. 
2) Утвердительные формы 3-го лица множественного числа функционируют в памятнике без маркеров лица и числа (-з-bl), употребление которых в литературном языке также носит факультативный характер: возильлям 'они, оказывается, держали' 2PST.3PL - литер. возиллям(зы); кӧлӥльлям 'они, оказывается, переночевали' 2PST.3PL - литер. кӧлӥллям(зы); кошкильлям 'они, оказывается, ушли' 2PST.3PL — литер. кошкиллям(зы) и др.

3) Отрицательные формы образуются в тексте синтетическим способом:

дӥсьтымтээ 'он, оказывается, не осмелился' NEG.2PST.3SG - литер. дӥсьтылмтэ(ез) / ӧвӧл дӥсьтэм (ез);

луымтэ ‘он, оказывается, не стал' NEG.2PST.3SG - литер. луымтэ(ез) / ӧвӧл луэм(ез); ciblмmэ ‘он, оказывается, не съел’ NEG.2PST.3SG - литер. сиымтэ(ез) / ӧвӧл сием(ез) и др.

4) Отрицательные формы 3-го лица множественного числа в [Житие] не имеют в своем составе элемента -лля-:

верамтэзы 'они, оказывается, не сказали' NEG.2PST-3-PL - литер. вераллямтэ(зы) / ӧвӧл верал$\operatorname{лям}(3 ы)$;

тэрымтэзы 'они, оказывается, не вместились' NEG.2PST-3-PL - литер. тэриллямтэ(зы) / ӧвӧл тэриллям(зы).

Все эти особенности в целом характерны для отдельных говоров южноудмуртского наречия [Кельмаков 2006: 150-152]. Что же касается функционирования в [Житие] отрицательных форм 3-го лица множественного числа без -лля-, в данном случае, вероятно, в памятнике представлены более ранние формы, а в литературном - более поздние, поскольку здесь они дополнительно «осложнены суффиксом

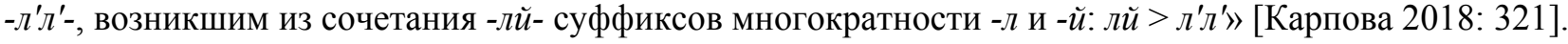

Из сложных временных форм в памятнике встречаются лишь две разновидности:

а) прошедшее длительное время:

вань вылэм 'имелся' PRS.3SG AUX — литер. вань вылэм;

уг зор вылэм 'дождь не шел’ NEG.PRS.3SG AUX — литер. уг зор вылэм.

б) прошедшее многократное время:

кошкоз вылэм 'он уйдет, бывало' FUT-3SG AUX - литер. кошкоз вылэм, вералоз вылэм 'он скажет, бывало' FUT-3SG AUX — литер. вералоз вылэм, пыроз вылэм 'он зайдет, бывало' FUT-3SG AUX — литер. пьроз вылэм; вӧсялозы вылэм 'они освятят, бывало’ FUT-3-PL AUX - литер. вӧсялозы вылэм.

Как видим, никаких отклонений в образовании этих форм по сравнению с литературной нормой не наблюдается.

3.2.2. В тексте «Жития Св. Феодора» форма повелительного наклонения единственного числа, как и в современном удмуртском языке, не имеет морфологического маркера, т. е. совпадает с глагольной основой': берыкты 'верни' IMP.2SG - литер. берыкты, валэкты 'разъясни' IMP.2SG - литер. валэкты, ёна 'излечись' IMP.2SG - литер. йӧна и др. При этом конечная гласная основы -bl при отсутствии сочетания согласных в корне слова, как правило, выпадает: тау кар 'поблагодари' IMP.2SG - литер. тау кар (< may карыны 'благодарить, поблагодарить'), ул 'живи' IMP.2SG - литер. $у л$ (<yлыны 'жить, прожить') и др.

Морфологическими показателями утвердительных форм множественного числа в литературном языке являются суффиксы -э(лэ)/-е(лэ) (І спряжение) и -лэ (II спряжение). К сожалению, подобные примеры в памятнике отсутствуют.

Отрицательные формы повелительного наклонения образуются путем сочетания не изменяемого по лицам и числам препозитивного глагола эн 'не' с соответствующими утвердительными формами: вождэ эн вай 'не сердись' NEG.IMP.2SG - литер. вождэ эн вай, эн басьтэ 'не забирайте' NEG.IMP-2PL — литер. эн басьтэ(лэ).

Кроме синтетического способа образования императивных форм, в удмуртском языке выделяют также аналитический способ, при котором глагол употребляется с препозитивными неизменяемыми частицами мед или медам (медад, медаз): мед мыноз 'пусть он пойдет', медам лыктыь 'пусть он не приходит' и т. д. [УКК 2011: 168]. В [Житие] подобный пример лишь один: медаз кульл 'пусть он не умрет' NEG.IMP.3SG - литер. медаз куль.

${ }^{3}$ Ударение при этом переходит на первый слог слова: ве́mлы 'сходи', ду́zды 'остановись', '́жа 'работай' и др. [УКК 2011: 164]. 
3.2.3. Морфологическим маркером сослагательного наклонения в удмуртском языке является суффикс -сал, к которому в формах единственного числа 2-го и 3-го лица, а также в формах множественного числа во всех трех лицах, как правило, присоединяются маркеры лица и числа: мон гожъясал 'я бы писал', тон гожъясал(ыд) 'ты бы писал', со гожъясал(ызз) 'он бы писал', ми гожъясалмы 'мы бы писали', тӥ гожъясалды 'вы бы писали', соос гожъясалзы 'они бы писали' [УКК 2011: 161]. Однако проверить, соответствуют ли сослагательные формы памятника литературным и современным диалектным вариантам, мы не можем из-за отсутствия соответствующих примеров в тексте.

3.2.4. Помимо трех основных, некоторые ученые выделяют в удмуртском языке еще желательное наклонение. Полные парадигмы спряжения зафиксированы в говоре д. Муважи Алнашского района УР, кукморском, кырыкмасских и некоторых других южноудмуртских говорах [Кельмаков 2006: 145-146]. В северном и бесермянском наречиях, а также в срединных говорах на данный момент сохранились лишь формы 3-го лица, которые сейчас рассматриваются в парадигме повелительного наклонения. По мнению В. К. Кельмакова, о существовании и дальнейшем распаде в этих говорах целостной парадигмы желательного наклонения свидетельствует тот факт, что «в отрицательном аспекте для выражения 3-го лица употребляется отрицательная вспомогательная часть как 1-го лица (мэдам), так и 3-го лица (мэдаз)» [Кельмаков 2006: 146].

В [Житие] нам удалось выявить лишь несколько утвердительных форм: две формы 1-го лица и три формы 3-го лица единственного числа:

мед пыром вал 'пусть бы я вошел' OPT.1SG - литер. мед пыром вал, мед кулом вал 'пусть бы я умер' OPT.1SG - литер. мед кулом вал;

мед кароз вал 'пусть бы он сделал' ОPT.3SG - литер. мед кароз вал, мед коттоз вал 'пусть бы он смочил’ OPT.3SG - литер. мед коттоз вал, мед кулоз вал 'пусть бы он умер’ OPT.3SG - литер. мед кулоз вал.

Несмотря на отсутствие полной парадигмы в памятнике, наличие форм первого лица, на наш взгляд, свидетельствует о том, что в тексте представлено желательное наклонение, которое в большинстве современных говоров уже не выделяется.

\section{3. Неспрягаемые формы глагола}

К неспрягаемым формам глагола в удмуртском языке относят инфинитив, причастия и деепричастия.

3.3.1. Морфологическим показателем инфинитива в [Житие], как и в удмуртском литературном языке и в абсолютном большинстве диалектов, является аффикс -ны: вӧсяськыныb 'молиться' - литер. вӧсяськыны, мыныны 'идти' - литер. мыныны, ӥоксаны 'закрыть' - литер. ӥоксаны и др.

3.3.2. Причастия в памятнике оформлены следующими морфологическими показателями:

1) -ücb:

льктӥсьь 'приходящий' — литер. лыктӥсь, улӥсь 'живущий' — литер. улӥсь

2) -эм/-ем (от глаголов I спряжения), - $\boldsymbol{м}$ (от глаголов II спряжения):

лэзем 'посланный' - литер. лэзем, лэсьтэм 'сделанный' - литер. лэсьтэм, котыртэм 'огороженный' - литер. котыртэм и др.;

вӧтам 'увиденный во сне' - литер. вӧтам;

3) -оно:

кулоно 'которому предстоит умереть' — литер. кулоно, паймоно 'которому предстоит удивиться' — литер. паймоно;

4) -он/-ён:

кыльлён 'предназначенный для лежания' - литер. кыллён, люкаськон 'предназначенный для встречи' - литер. люкаськон, улон 'предназначенный для житья' - литер. улон и др.;

5) -мон:

улымон 'достаточный для жизни' - литер. ульммон;

6) -мтэ:

кульммтэ 'не умерший' — литер. кульымтэ;

7) -онтэм:

бертонтэм ‘безвозвратный’ - литер. бертонтэм.

Как видим, никаких отклонений в образовании причастных форм в анализируемом тексте не наблюдается. 


\subsection{3. Деепричастия в памятнике оформлены следующими формантами:}

1) -ca:

курыса 'прося' - литер. курыса, пегӟыса 'убежав' - литер. пегӟыса, тодыса 'узнав' - литер. тодысса и др.;

жаляса 'пожалев' - литер. жаляса, кышкаса 'боясь' — литер. кышкаса, малпаса 'думая' литер. малпаса и др.

2) -тэк:

бертытэк 'не возвращаясь домой' - литер. бертымэк, дышетытэк 'не обучив' - литер. дышетытэк, потылээк 'не желая' - литер. потытэк и др.

Кроме основного суффикса -тэк, который встречается в восьми формах, в двух примерах представлен вариант -тэг: висьылтэг 'не болея' - литер. висьылтэк, лэзыытэг 'не отпуская' — литер. лэзьытэк. Стоит отметить, что подобный алломорф ранее был отмечен и в памятнике на казанском наречии удмуртского языка [Безенова 2018: 21], но, к сожалению, в других источниках и в современных диалектах следов подобного варианта мы еще не встречали, поэтому на данный момент делать какие-либо выводы о происхождении этого алломорфа мы не можем.

3) -кы:

аӟыкыз ‘когда он видит' 3SG - литер. адӟыкуз, бертыкыз ‘когда он возвращается домой’ 3SG литер. бертыкуз, ветлыкызы 'когда они ходят' 3-PL - литер. ветлыкузы и др.

Маркер -кы, который употребляется в памятнике в соответствии с литературным -кy, по своему происхождению считается более архаичным (см. подробнее [Серебренников 1963: 302]). Этот вариант представлен на данный момент в говорах южной диалектной зоны [Атаманов 1981: 55, 2005: 188; Загуляева 1982: 6; Кельмаков 2006: 159], в бесермянском наречии [Тепляшина 1970: 253], а также в нижнечепецком диалекте северного наречия удмуртского языка [Карпова 2018: 357]. Для остальных северноудмуртских диалектов характерен формант -кy, который закрепился и в современном литературном языке.

Кроме того, из приведенных примеров видна еще одна особенность: деепричастия, оформленные суффиксом -кbl, а также суффиксом -тось (-тося-), который будет рассмотрен далее, в отличие от предыдущих глагольных форм, могут изменяться по лицам и числам.

4) -тось (-тося-):

вӧсяськытось 'пока молишься' - литер. вӧсяськытозь, кулытосязы 'до их смерти' 3-PL — литер. кульгтозязыл.

Как видим, в данном случае показатель, выявленный в памятнике, также не совпадает с литературным суффиксом. В диалектах удмуртского языка сегодня выделяют несколько алломорфов маркера -тозь (-тос', -тоӟ, -ӥчож, -ччож, -ччоз' (-чоз') [Кельмаков 2006: 157-158]). Вариант -тос', зафиксированный нами в [Житие], по данным диалектологов, распространен в кукморском, шошминском и бавлинском говорах периферийно-южного диалекта [Кельмаков 2006: 157]. Возможно, этот маркер встречается и в современных говорах центрально-южного диалекта удмуртского языка, но из-за низкого уровня изученности данного ареала такие примеры еще не выявлены.

\section{4. Выводы}

Итак, в переводе «Жития Св. Феодора» на морфологическом уровне можно выделить ряд особенностей, в отношении которых язык памятника отличается от современного литературного удмуртского языка и некоторых его диалектов:

1) образование множественного числа имен существительных от основ с конечной гласной с помощью суффикса -ёс;

2) употребление в формах разделительного падежа параллельно с аффиксом -лэсь маркера -лӥсь;

3) функционирование элативных и эгрессивных показателей в $u$-овой огласовке;

4) образование терминатива с помощью суффикса -ось;

5) функционирование двух модификаций залогового аффикса -иськ(bl)-/-ӥськ(bl)- - - $(b l)-$ и -чк(bl)-;

6) отсутствие в отрицательных формах прошедшего неочевидного времени 3-го лица множественного числа элемента -лля-;

7) наличие форм желательного наклонения;

8) образование деепричастий, обозначающих дополнительное действие, протекающее одновременно с основным, с помощью маркера -кbl; 
9) функционирование деепричастий, указывающих на действие, до осуществления которого происходит другое действие, с показателем -тось (-тося-).

Из девяти перечисленных особенностей, выявленных нами в тексте, четыре (пп. $3,4,5,9)$ имеют инновационный характер. При этом все они зафиксированы в современных южноудмуртских говорах, что не противоречит гипотезе, выдвинутой на основе анализа фонетической системы памятника, согласно которой диалектной основой «Жития Св. Феодора» является один из центрально-южных говоров [Безенова 2021: 47].

К сожалению, нам не удалось однозначно объяснить функционирование некоторых особенностей в [Житие]. В какой-то мере, вероятно, это связано с небольшим объемом памятника, но главным образом, на наш взгляд, на это повлияло отсутствие комплексных описаний большинства удмуртских диалектов. В первую очередь это относится к центрально-южным говорам, которые по сей день фактически остаются белым пятном в удмуртской диалектологии.

\section{Сокращения}

\section{Языки и диалекты}

бес. - бесермянское наречие

бтБК. - буйско-таныпский говор деревни Большой Ка-

чак (Калтасинский район Башкортостана)

канл. — канлинский говор

кркм. - кырыкмасские говоры

кукм. - кукморский говор

к.-3. - коми-зырянский язык
к.-П. - коми-пермяцкий язык

к.-я. - коми-язьвинский язык литер. - литературная форма, литературный язык сред. - срединные говоры шошм. - шошминский говор юж. - центрально-южный диалект

диалекты по [Wichmann 1987]:

В - бесермянский диалект

$\mathrm{G}$ - глазовский диалект

$\mathrm{J}$ - елабужский диалект

M - малмыжский диалект
MU — малмыжско-уржумский диалект

$\mathrm{S}$ - сарапульский диалект

$\mathrm{U}$ - уфимский диалект

Глоссы

1, 2, 3 - первое, второе, третье лицо

1PST - первое (очевидное) прошедшее время

2PST - второе (неочевидное) прошедшее время

$\mathrm{ABL}$ - аблатив

ACC - аккузатив

AUX - вспомогательный глагол

CAUS - понудительный залог

CONV - деепричастие

DAT - датив

EGR - эгрессив

ELA - элатив

FUT - будущее время

ILL — иллатив

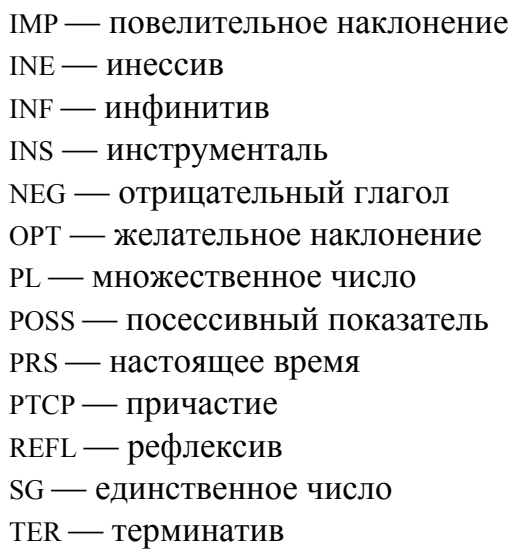

Литература

Алашеева 1982 - Аламеева А. А. Верхнечепецкие говоры I // Образцы речи удмуртского языка. Ижевск, 1982. C. 91-105. \{Alasheeva A. A. Upper-Cheptsa Dialects I // Speech Samples of the Udmurt Language. Izhevsk, 1982. P. 91-105.\}

Архипов 1978 - Архипов Г. А. Морфологические особенности среднеюжного диалекта удмуртского языка I // О диалектах и говорах южноудмуртского наречия: Сборник статей и материалов. Ижевск, 1978. С. 3 - 46. \{Arkhipov G. A. Morphological Features of the Udmurt Middle-Southern Dialect I // About Dialects and Subdialects of the Southern Udmurt Dialect: Collection of Papers and Materials. Izhevsk, 1978. P. 3 - 46.\} 
Атаманов 1981 - Атаманов М. Г. Граховские говоры южноудмуртского наречия // Материалы по удмуртской диалектологии. Ижевск, 1981. С. 45-96. \{Arkhipov G. A. Grakhov Dialects of the South Udmurt Dialect// Materials on Udmurt Dialectology: Speech Samples. Izhevsk, 1981. P. 45-96.\}

Атаманов 2005 - Атаманов М. Г. От Дондыкара до Урсыгурта. Из истории удмуртских регионов. Ижевск, 2005. \{Atamanov M. G. From Dondykar to Ursygurt. From the History of the Udmurt Regions. Izhevsk, 2005.\}

Баталова 1993а - Баталова Р. М. Коми(-зырянский) язык // Языки мира: Уральские языки. Москва, 1993. С. 214 -229. \{Batalova R. M. Komi(-Zyrian) Language // Languages of the World: Uralic Languages. Moscow, 1993. P. 214-229.\}

Баталова 1993б - Баталова Р. М. Коми-пермяцкий язык // Языки мира: Уральские языки. Москва, 1993. С. 229 -239. \{Batalova R. M. Komi-Permian Language // Languages of the World: Uralic Languages. Moscow, 1993. P. 229_239.\}

Безенова 2018 - Безенова М. П. «Наставление христианское святителя Тихона на вотском языке» (1891) («Ӟеч кылъёс. Святой Тихонлэн ӟечлы дышетэм кылъёсыз»): глагольная морфология // Урало-алтайские исследования. 2018, 1 (28). С. 7-22. \{Bezenova M. P. "Christian Admonition of St. Tikhon in the Votyak Language" (1891): Verbal Morphology // Ural-Altaic Studies. 2018, 1 (28). P. 7-22.\}

Безенова 2021 - Безенова М. П. Фонетические особенности «Жития Св. Феодора» (1913) на удмуртском языке // Урало-алтайские исследования. 2021, 2 (41). С. 21-50. \{Bezenova M. P. Phonetic features of the "Life of St. Theodore" (1913) (written) in the Udmurt language // Ural-Altaic Studies. 2021, 2 (41). P. 21-50.\}

ГСУЯ 1962 - Грамматика современного удмуртского языка: Фонетика и морфология / Отв. ред. П. Н. Перевощиков. Ижевск, 1962. \{Grammar of the Modern Udmurt Language: Phonetics and Morphology. Izhevsk, 1962.\}

Житие - Святой Өеодорлэн улэмез. Житіе Св. Өеодора: На вотскомъ языкъ елабужскаго нарьчія. Первое изданіе Переводческой Комиссіи 3-го благочинническаго округа, Елабужскаго уъзда, Вятской Епархіи. Казань: Центральная типографія, 1913. 19 с. \{Life of St. Theodore: In the Elabuga dialect of the Votyak Language. The first edition of the Translation Commission of the $3^{\text {rd }}$ Deanery District, Elabuga District, Vyatka Eparchy. Kazan: Central Printing House, 1913. 19 p.\}

Загуляева 1982 - Загуляева Б. Ш. Говоры удмуртов Кизнерского района // Образцы речи удмуртского языка. Ижевск, 1982. С. 5-27. \{Zagulyaeva B. Sh. Dialects of the Kizner District Udmurts // Speech Samples of the Udmurt Language. Izhevsk, 1982. Р. 5-27.\}

Карпова 2018 - Карпова Л. Л. Диалекты северного наречия удмуртского языка: формирование и современное состояние. Дисс. ... докт. филол. наук. Ижевск, 2018. \{Karpova L. L. Dialects of the Northern Dialect of the Udmurt Language: Formation and Current Status. Doctoral thesis. Izhevsk, 2018.\}

Кельмаков 1993 - Кельмаков В. К. Формирование и развитие фонетики удмуртских диалектов. Ижевск, 1993. \{Kelmakov V. K. Formation and Development of Phonetics of the Udmurt Dialects. Izhevsk, 1993.\}

Кельмаков 2006 - Кельмаков В. К. Краткий курс удмуртской диалектологии: Учебное пособие для высших учебных заведений. 2-е изд. Ижевск, 2006. \{Kelmakov V. K. Short Course of Udmurt Dialectology: Textbook for Higher Educational Institutions. $2^{\text {nd }}$ ed. Izhevsk, 2006. $\}$

Кондратьева 2011a - Кондратьева Н. В. Категория падежа имени существительного в удмуртском языке. Ижевск, 2011. \{Kondratyeva N. V. Category of the Nominative Case in the Udmurt Language. Izhevsk, 2011.\}

Кондратьева 20116 - Кондратьева Н. В. Словоизменение имени существительного в удмуртском языке (грамматические категории падежа и числа). Автореф. дисс. ... докт. филол. наук. Ижевск, 2011. \{Kondratyeva N. V. Variation of Nouns in the Udmurt Language (Grammatical Categories of Case and Number). Summary of a Doctoral thesis. Izhevsk, 2011.\}

Кондратьева 2011в - Кондратьева Н. В. Формирование падежной системы в удмуртском языке. Ижевск, 2011. \{Kondratyeva N. V. The Formation of the Case System in the Udmurt Language. Izhevsk, 2011.\}

Лыткин 1931 - Лыткин В. И. К происхождению суффикса множественного числа jos в удмуртском языке // На удмуртские темы: Сб. статей. Вып. II. Москва, 1931. С. 101-111. \{Lytkin V. I. On the Origin of the Plural Suffix "jos" in the Udmurt Language // Udmurt Topics: Collection of Papers. Vol. II. Moscow, 1931. P. 101-111.\}

Серебренников 1963 - Серебренников Б. А. Историческая морфология пермских языков. Москва, 1963. \{Serebrennikov B. A. Historical Morphology of Perm Languages. Moscow, 1963.\}

Тараканов 1960 - Тараканов И. В. Некоторые явления ассимиляции, элизии и вставки звуков в удмуртском языке: На материале бавлинского диалекта // Труды Института языка и литературы АН ЭССР. Таллин, 1960. Вып. 5. C. 117-153. \{Tarakanov I. V. Some Phenomena of Assimilation, Elision and Insertion of Sounds in the Udmurt Language: On the Material of the Bavly Dialect // Proceedings of the Institute of Language and Literature of the Academy of Sciences of the ESSR. Tallinn, 1960. Issue 5. P. 117-153.\}

Тепляшина 1970 - Тепляиина Т. И. Язык бесермян. Москва, 1970. \{Tepliashina T. I. The Beserman Language. Moscow, 1970.\}

Тепляшина 1975 - Тепляшина Т. И. Употребление формантов аккузатива множественного числа в удмуртских диалектах // СФУ. 1975, XI. С. 179-185. \{Teplyashina T. I. The Use of Plural Accusative Formants in the Udmurt Dialects // Soviet Finno-Ugric Studies. 1975, XI. P. 179-185.\} 
УКК 2011 - Удмурт кыллэн кылкабтодосэз (морфологиез): Тодослыко-дышетскон издание (Морфология удмуртского языка: Научно-учебное издание) / Отв. ред. Н. Н. Тимерханова. Ижевск, 2011. \{Morphology of the Udmurt Language: Scientific and Educational Publication / Ed. N. N. Timerkhanova. Izhevsk, 2011.\}

Усачева 2011 - Усачева М. Н. Показатели элатива, эгрессива и аблатива в пермских языках: сфера употребления и зоны конкуренции // Acta linguistica Petropolitana. Труды Института лингвистических исследований. 2011. Т. 7. Часть 3. С. 208-213. \{Usacheva M. N. Indicators of Elative, Egressive and Ablative in Permian Languages: Sphere of Use and Zones of Competition // Acta Linguistica Petropolitana. Proceedings of the Institute of Linguistic Research. 2011. Vol. 7. Part 3. P. 208-213.\}

Fokos 1963 — Fokos D. [рец.] Грамматика современного удмуртского языка: Фонетика и морфология. Ижевск, 1962 // Nyelvtudományi Kozlemények. 1963, 1 (66). 215-218 old.

Kövesi 1965 - Kövesi M. A permi nyelvek ösi képzői. Budapest, 1965.

Uotila 1933 - Uotila T. E. Zur Geschichte des Konsonantismus in den permischen Sprachen. Helsinki, 1933.

Wichmann 1987 — Wichmann Y. Wotjakischer Wortschatz / Aufgezeichnet Y. Wichmann. Bearb. T. E. Uotila, M. Korhonen. Hrsg. M. Korhonen. Helsinki, 1987. (Lexica Societatis Fenno-Ugricae. 1987, XXI.) 